\title{
QUALITY OF THE STRUCTURE OF ASH BODIES BASED ON DIFFERENT TYPES OF ASH
}

\author{
KVALITETA STRUKTURE TELESA IZ PEPELA NA OSNOVI \\ RAZLIČNIH VRST PEPELA
}

\author{
Vit Cerny \\ Brno University of Technology, Faculty of Civil Engineering, Veveri 95, 60200 Brno, Czech Republic \\ cerny.v@fce.vutbr.cz \\ Prejem rokopisa - received: 2014-08-21; sprejem za objavo - accepted for publication: 2014-09-25
}

doi:10.17222/mit.2014.207

\begin{abstract}
Artificial aggregates based on the self-firing process are often produced with an outdated technology without innovations and research. The knowledge of the production of ceramic materials is useful, but fly ash is quite a heterogeneous material influenced by the thermal processes occurring during the production; therefore, this problem has to be solved. The aim of the research work was to evaluate the influence of the character of fly ash on the formation, structure and properties of a sintered fly-ash body using laboratory firings. The main difference as regards the behavior is between the fly ash originating from high temperature and the one originating from fluidized-bed combustion. While the first type of ash contains mainly mullite and other high-temperature minerals, the fluidized-bed-combustion ash contains mainly anhydrite and free lime. These increase, for example, the manipulation strength of a fly-ash mix, but they also increase the amount of mixing water and weaken a sintered fly-ash body. The content of $\mathrm{Fe}_{2} \mathrm{O}_{3}$ and its modifications and the proportion of $\mathrm{SiO}_{2}$ in the amorphous phase or mullite are important parameters for evaluating various types of high-temperature combustion fly ashes. The content of $\mathrm{Fe}_{2} \mathrm{O}_{3}$ together with carbon finally works as a very effective fluxing agent. Thus, the surface of a specimen was sintered and the swelling was considerable due to the product gases of $\mathrm{CO}$ and $\mathrm{CO}_{2}$. A higher proportion of $\mathrm{SiO}_{2}$ contained in the amorphous phase increases the strength and the quality of a fly-ash body. A higher proportion of $\mathrm{SiO}_{2}$ in the crystal phase requires a higher amount of heat for obtaining a solid structure.

Keywords: artificial aggregate, bottom ash, fly ash, FBC ash, sintering, clinkering
\end{abstract}

Umetna telesa, ki temeljijo na procesu zgorevanja, se pogosto izdelujejo po zaostali tehnologiji, brez inovacij in raziskav. Poznanje izdelave keramičnih materialov je koristno, vendar pa je leteči pepel zelo heterogen material, na katerega vplivajo toplotni procesi med proizvodnjo, zato je ta problem potrebno rešiti. Namen te preiskave je bil oceniti vpliv značilnosti letečega pepela na nastanek, strukturo in lastnosti teles iz sintranega letečega pepela z laboratorijskim žganjem. Glavna razlika glede na vedenje je med letečim pepelom, ki izvira iz visokih temperatur in tistim, ki izvira iz zgorevanja v zvrtinčeni plasti. Medtem ko prva vrsta pepela vsebuje pretežno mulit in druge visokotemperaturne minerale, vsebuje pepel iz zgorevanja v zvrtinčeni plasti predvsem anhidrit in prosto apno. To na primer poveča manipulacijsko trdnost mešanice letečega pepela, vendar poveča tudi količino mešalne vode in oslabi telo iz sintranega letečega pepela. Vsebnost $\mathrm{Fe}_{2} \mathrm{O}_{3}$ in njegovih modifikacij ter razmerja $\mathrm{SiO}_{2} \mathrm{~V}$ amorfni fazi ali mulitu sta pomembna parametra pri oceni različnih vrst visokotemperaturnih letečih pepelov. Vsebnost $\mathrm{Fe}_{2} \mathrm{O}_{3}$ skupaj z ogljikom deluje kot zelo učinkovito talilo. Površina vzorcev je bila sintrana in pojavilo se je občutno nabrekanje zaradi nastajanja plinov $\mathrm{CO}$ in $\mathrm{CO}_{2}$. Večji delež vsebnosti $\mathrm{SiO}_{2} \mathrm{v}$ amorfni fazi je povečala trdnost in kvaliteto telesa iz letečega pepela. Večja vsebnost $\mathrm{SiO}_{2}$ v kristalni fazi povzroča potrebo po večji količini toplote za pridobivanje trdne strukture.

Ključne besede: umetno telo, pepel, leteči pepel, FBC-pepel, sintranje, negorljiv ostanek

\section{INTRODUCTION}

Even after its previous treatment, a big part of the produced fly ash is still stored at a storing place and the cost for its liquidation is still considerable. ${ }^{1}$ Generally, the volume of suitable fly-ash types produced in our country highly exceedes the possibilities of its processing in the building industry. ${ }^{2}$

In the first period of realisation our building industry is able to use suitably sintered artificial aggregates in the volume of $300-400 \cdot 10^{3} \mathrm{~m}^{3}$ annually. ${ }^{3}$ After its application has been generally accepted in the building industry this volume may continually increase. A former experience confirmed this expectation when the complete production of the Dertmarovice agglomeration factory (the Corson technology) was troublefree and used mostly in the North Moravia region. Considering the limited knowledge in this field, the operation and optimisation of this technology were very expensive and fly ash found its place in the traditional technologies of concrete production. ${ }^{4-6}$

The European and global trends in the new-technology development in the building industry require a production of high-quality light artificial aggregates, and its operation is increasing in the advanced countries. ${ }^{7,8}$

In Central and Eastern Europe, only Poland reacted to this trend by constructing a factory for the artificialaggregate production using the sintered fly ash in Gdansk. The factory is equipped with licensed process equipment from Lytag, UK. However, the technology of this production process is even older than the Corson technology. ${ }^{9}$

The production technology for obtaining artificial aggregates by burning frequently uses the original format 
of high-quality black-coal fly ash containing the optimum amount of unburned residues, burned with an external heat source and without the necessary correction of the fuel or the aggregate. Globally, there is no competition within this field and thus the involved companies do not commit to development and innovations. On that ground the procedures of obtaining artificial aggregates from sintered fly ash are relatively poorly explored and only a minimum scientific work is dedicated to the process of producing fly-ash bodies by burning. Therefore, if we consider the possibility of restoring the production in inland conditions it is necessary not only to innovate the existing technology but also, in particular, to commit to the study of reaction processes in the solid phase and the creation of fly-ash aggregates.

\section{EXPERIMENTAL WORK}

At the beginning the experimental activity was focused on the characterization of the selected types of ashes, representing the current production plants of the Czech Republic. We selected five samples of fly ashes obtained with the combustion of coal at temperatures of 1200-1600 ${ }^{\circ} \mathrm{C}$, with its desulphurization taking place after the separation by means of a lime solution. We had one sample of black-coal fly ash (FFA), three samples of brown-coal fly ashes from the silos of three different power plants (FA1, FA2, FA3s) and one sample of a finer fly ash (2nd electrostatic separator) from the third plant (FA3f). There were also two samples from a power plant with the fluidized-bed combustion (FBC) of brown coal. This type of combustion takes place at the temperatures of around $850{ }^{\circ} \mathrm{C}$ and desulphurization is carried out in the furnace. One sample was from the electrostatic separator (FBC FA) and one from the bottom of the furnace (FBC BA).

The following physico-mechanical and physico-chemical parameters were selected: the loss on ignition (ČSN 72 0103) showing unburned residues, the bulk density (ČSN 72 2071), the specific surface area and remains on the sieve of $0.090 \mathrm{~mm}$ (CSN 72 2072-6). The chemical and mineralogical analyses were also carried out.
In order to monitor the behavior of the samples during the firing process, a special type of annealing microscopy was chosen. Cylinders of $3 \mathrm{~mm}$ in cross-section were made. They were placed into an annealing chamber equipped with a camera and backlight to capture the changes in the sample cross-sections during the annealing $\left(10^{\circ} \mathrm{C} / \mathrm{min}\right.$, max. $\left.1600{ }^{\circ} \mathrm{C}\right)$. The current temperature and the changes to the sample cross-sectional areas were primarily recorded.

The influence of fly ash on the physico-mechanical properties of a fired ceramic body was determined on the samples fired in a muffle kiln. Fly ash was mixed with water to reach the limit of fluidity. We made samples with the size of $20 \mathrm{~mm} \times 20 \mathrm{~mm} \times 100 \mathrm{~mm}$ that were, next day, dried at $60{ }^{\circ} \mathrm{C}$ for $2 \mathrm{~h}$ and then fired in the muffle kiln. The firing was characterized by the initial temperature of $25^{\circ} \mathrm{C}$, a rate of firing the muffle kiln of $300{ }^{\circ} \mathrm{C} / \mathrm{h}$ and an isothermal dwell time at $1150{ }^{\circ} \mathrm{C}$ of 10 min. After the firing and natural cooling down, the specimens were taken out of the kiln and placed in a desiccator. After a thermal stabilization, their volume weight (ČSN EN 1015-10 and ČSN EN 1015-6), the compressive strength (ČSN EN 14617-15) and the water-absorbing capacity (ČSN EN 1097-6) were determined.

\section{RESULTS AND DISCUSSION}

First of all there are the results characterizing the ashes tested. In Table 1 you can see the results determining the physico-mechanical and physico-chemical parameters and the results of the chemical analysis.

The analysis of the unburned residues of the tested fly ash shows that apart from fly ash FFA, all the samples fulfill the requirements of the standard (CSN 72 2072-6, 2013) for the maximum loss on ignition of $15 \%$. Therefore, this fly ash was used as the fuel (FuelFlyAsh) in this work. The determination of the bulk density shows that the fly ash from high-temperature combustion reaches higher values than the fly ash from fluidized-bed combustion. All the values of the high-temperature fly-ash samples and the bottom ash fulfill the requirements of the standard (CSN 72 2072-6, 2013) for the minimum value of $800 \mathrm{~kg} \mathrm{~m}^{-3}$. The low values of the bulk density of samples FFA and FBC show a porous structure of the coal grains.

Table 1: Physico-mechanical and physico-chemical parameters of the tested ashes

Tabela 1: Fizikalno-mehanski in fizikalno-kemijski parametri preizkušanih pepelov

\begin{tabular}{|c|c|c|c|c|c|c|c|c|c|}
\hline & $\begin{array}{c}\text { Loss on } \\
\text { ignition }\end{array}$ & $\begin{array}{c}\text { Bulk } \\
\text { density }\end{array}$ & $\begin{array}{c}\text { Specific } \\
\text { surface }\end{array}$ & $\begin{array}{c}\text { Remains on the } \\
\text { sieve, } 0.090 \mathrm{~mm}\end{array}$ & \multicolumn{4}{|c|}{ Chemical composition $(\%)$} \\
\hline & $\%$ & $\mathrm{~kg} \mathrm{~m}^{-3}$ & $\mathrm{~m}^{2} \mathrm{~kg}^{-1}$ & $\%$ & $\mathrm{SiO}_{2}$ & $\mathrm{Al}_{2} \mathrm{O}_{3}$ & $\mathrm{Fe}_{2} \mathrm{O}_{3}$ & $\mathrm{SO}_{3}$ & $\mathrm{CaO}$ \\
\hline FA1 & 1.19 & 990 & 329 & 37 & 47.7 & 28.2 & 5.6 & 0.1 & 1.1 \\
\hline FA2 & 1.07 & 1110 & 299 & 33 & $\mathbf{5 4 . 6}$ & 29.5 & 5.5 & 0.1 & 1.8 \\
\hline FA3s & 2.39 & 1010 & 234 & 51 & 50.0 & 23.4 & $\mathbf{1 4 . 5}$ & 0.3 & 3.4 \\
\hline FA3f & 1.97 & 940 & 262 & $\mathbf{9}$ & 48.3 & 22.8 & $\mathbf{1 6 . 6}$ & 0.5 & 3.7 \\
\hline FFA & $\mathbf{2 7 . 1 2}$ & $\mathbf{8 3 0}$ & 398 & 33 & 36.0 & 16.4 & 8.9 & 0.4 & 5.0 \\
\hline FBCFA & 2.08 & $\mathbf{8 1 0}$ & 353 & 32 & 42.7 & 26.8 & 5.1 & $\mathbf{3 . 0}$ & $\mathbf{1 0 . 2}$ \\
\hline FBCBA & 4.23 & 1210 & $\mathbf{3 3}$ & $\mathbf{8 8}$ & 42.3 & 26.7 & 5.2 & $\mathbf{3 . 1}$ & $\mathbf{1 0 . 3}$ \\
\hline
\end{tabular}


Table 2: Results of the mineralogical analysis of the tested ashes

Tabela 2: Rezultati mineraloških analiz preizkušanih pepelov

\begin{tabular}{|c|c|c|c|c|c|c|c|c|}
\hline & Quartz & Mullite & Hematite & Anortite & Lime & Calcite & Anhydrite & Amorphous \\
\hline & $\mathrm{SiO}_{2}$ & $\mathrm{Al}_{6} \mathrm{Si}_{2} \mathrm{O}_{13}$ & $\mathrm{Fe}_{2} \mathrm{O}_{3}$ & $\mathrm{CaAl}_{2} \mathrm{Si}_{2} \mathrm{O}_{8}$ & $\mathrm{CaO}$ & $\mathrm{CaCO}_{3}$ & $\mathrm{CaSO}_{4}$ & phase \\
\hline Melting point $\left({ }^{\circ} \mathrm{C}\right)$ & 1470 & 1810 & 1350 & 1550 & 2613 & 825 & 1400 & - \\
\hline FA1 & 7.0 & 39.3 & 1.2 & 2.7 & - & - & - & 39.5 \\
\hline FA2 & 7.8 & 32.3 & - & - & - & - & - & 58.1 \\
\hline FA3s & 7.1 & 18.2 & 3.3 & 8.7 & - & - & - & 55.6 \\
\hline FA3f & 6.8 & 17.3 & 3.5 & 8.5 & - & - & - & 58.4 \\
\hline FFA & 13.0 & 12.4 & 2.0 & 4.2 & 0.8 & 0.5 & - & 57.5 \\
\hline FBCFA & 9.5 & - & 3.3 & - & 3.2 & 3.8 & 5.7 & 63.8 \\
\hline FBCBA & 8.8 & - & 3.4 & - & 3.4 & 3.6 & 5.9 & 58.9 \\
\hline
\end{tabular}

In most cases, the specific surface corresponds to the results of the granulometry of fly ash. Higher values show a better quality of the reaction in the solid phase and the formation of a stronger structure of the aggregate.

The results of the chemical analysis show that hightemperature ashes usually achieve a higher content of $\mathrm{SiO}_{2}$. FA2 has the highest value. The FBC ash samples achieved higher contents of $\mathrm{CaO}$ and $\mathrm{SO}_{3}$ as the sulphate sulphur. This helps us obtain higher strengths of fresh samples.

Because of the $\mathrm{SO}_{3}$ exceeding limits (CSN 72 2072-6, max. $3 \%$ ) it will be necessary to install desulphurization of the production line in the future. The content of $\mathrm{Fe}_{2} \mathrm{O}_{3}$ is an important parameter and it acts as a fluxing agent during the firing, enclosing the surface of an aggregate. Consequently, the fumes cannot leave freely and a reductive core is produced. The grains show a more considerable porosity under the surface. ${ }^{10}$ This problem can be assumed during the production of the aggregate based on fly ash FA3.

As you can see in Table 2, FA1 has the highest percentage of mullite and a lower content of the amorphous phase in comparison with FA2. The mineralogical analysis further confirms that FA3 contains more minerals with a lower melting point and a low content of mullite. Fluidized-bed ashes have almost no content of mullite. The FBC ashes achieve higher contents of the minerals

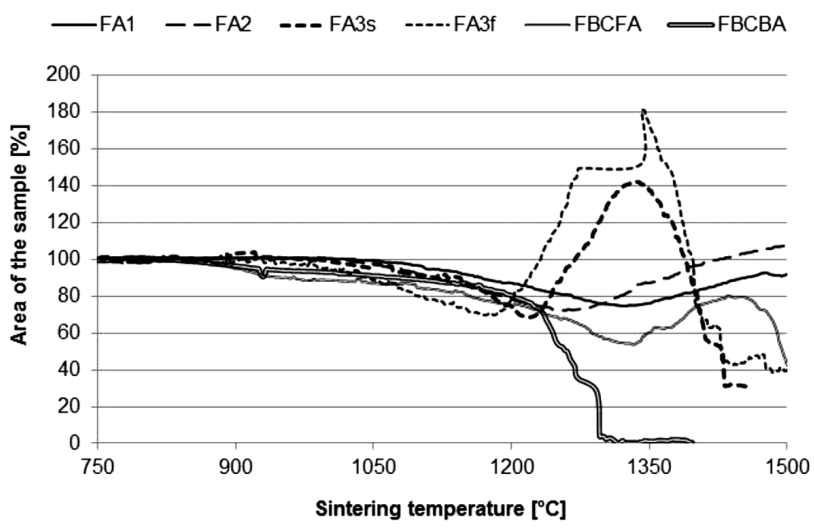

Figure 1: Changes to the sample cross-sectional area during annealing Slika 1: Spremembe prečnega prereza vzorcev med žarjenjem based on $\mathrm{CaO}$ that shorten the sintering interval and decrease the melting point of the material.

In Figure 1 you can see the results of the annealing microscopy. Specifically, there is a dependence of the area of the sample on the firing temperature. The samples are stable up to $1150{ }^{\circ} \mathrm{C}$. The samples of fly ashes went through a certain sintering phase, followed by the swelling caused by the generated gases. Higher contents of $\mathrm{Fe}_{2} \mathrm{O}_{3}$ in FA3s and FA3f, together with the carbon, cause a reduction in $\mathrm{FeO}$, which then functions as a highly active flux. ${ }^{10}$ This leads to the sintering of the sample surface and a subsequent significant swelling caused by the generated gases of $\mathrm{CO}$ and $\mathrm{CO}_{2}$. As you can see, the finer ash of FA3f achieves the highest swelling $(180 \%)$. This is one of the reasons why the rate of firing the muffle kiln of $300{ }^{\circ} \mathrm{C} / \mathrm{h}$ was chosen. A higher firing rate can create samples with unsuitable shapes. At the melting point, the melting starts. The annealing of fluid fly ash is significantly affected by the presence of $\mathrm{CaSO}_{4}, \mathrm{CaCO}_{3}$ or $\mathrm{CaO}$ alone. The first two minerals show their degradation during the firing and the subsequent percentage of $\mathrm{CaO}$ significantly lowers the melting point of the other minerals.

Figure 2 shows the results of the shrinkage; Figure 3 shows the compressive strength and Figure $\mathbf{4}$ the water absorption of the fired samples.

The highest shrinkage was measured for the samples based on the FBC ashes, exhibiting a higher porosity,

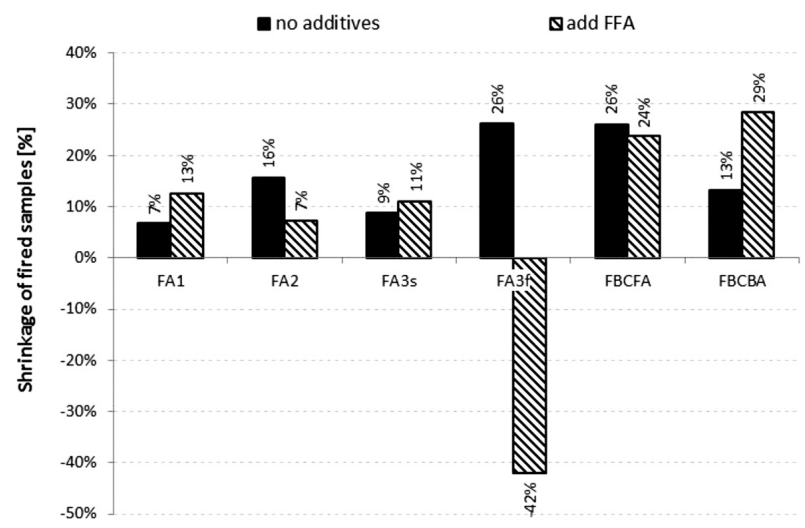

Figure 2: Shrinkage of the fired samples

Slika 2: Skrček žganih vzorcev 


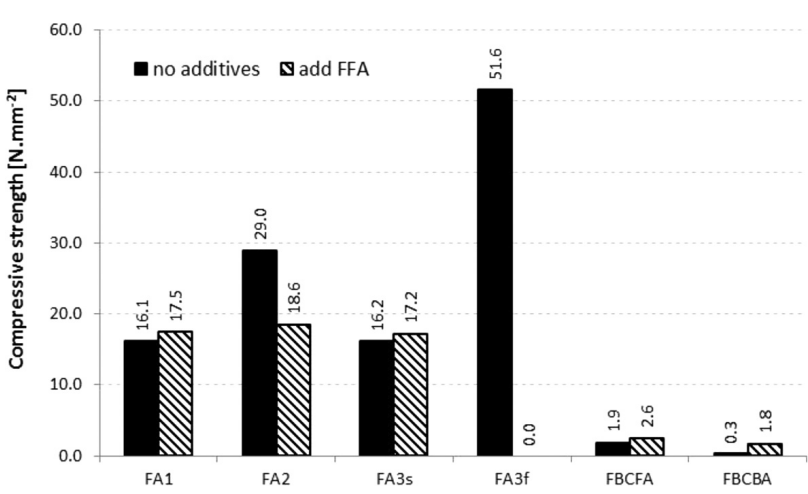

Figure 3: Compressive strength of the fired samples

Slika 3: Tlačna trdnost žganih vzorcev

and a decomposition of the $\mathrm{CaO}$ products caused a disintegration of the structure. This is the reason why a low compressive strength was also measured. An addition of high-temperature ash (FBC FA + $24 \%$ FFA; FBC $\mathrm{BA}+16 \%$ FFA) increased the strength only on a small scale.

A high shrinkage was also measured for the sample based on FA3f, which had the highest content of the particles under $0.009 \mathrm{~mm}$. Due to a higher content of $\mathrm{Fe}_{2} \mathrm{O}_{3}$ the highest compressive strength was measured. The shrinkage and closed porosity caused a very low water absorption. The addition of FFA as a fuel caused a high swelling (negative values for the shrinkage) and the samples then were not useable for the measurement of the physico-mechanical parameters.

The fly ashes from the silo (FA1, FA2, FA3s) had stable structures and achieved a lower shrinkage. A higher content of the amorphous phase and a low content of mullite caused higher compressive strengths of the FA2 samples. An addition of FFA (27\%) in combination with FA2 caused a structural weakening.

As you can see in Figure 4 high-temperature ashes achieved lower values of water absorption in comparison with the FBC ashes.

In Figures 5 and $\mathbf{6}$ you can see the differences between the samples based on the fly ashes with lower and higher contents of $\mathrm{Fe}_{2} \mathrm{O}_{3}$. Figure 5 shows the closed

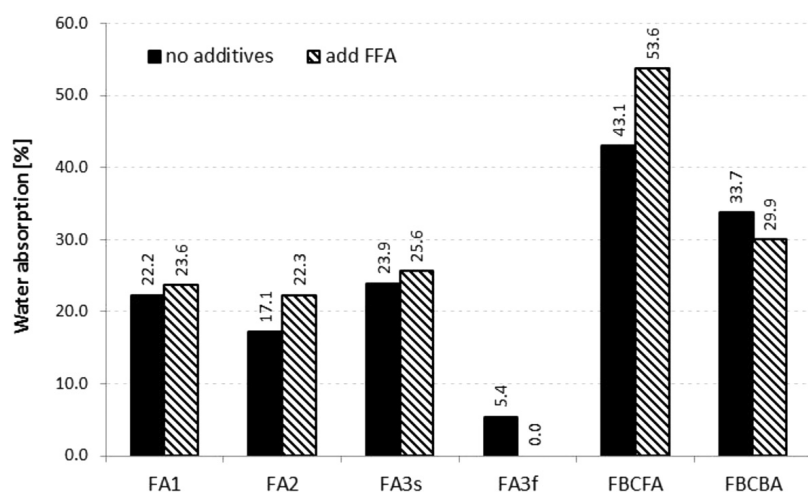

Figure 4: Water absorption of the fired samples Slika 4: Absorpcija vode žganih vzorcev

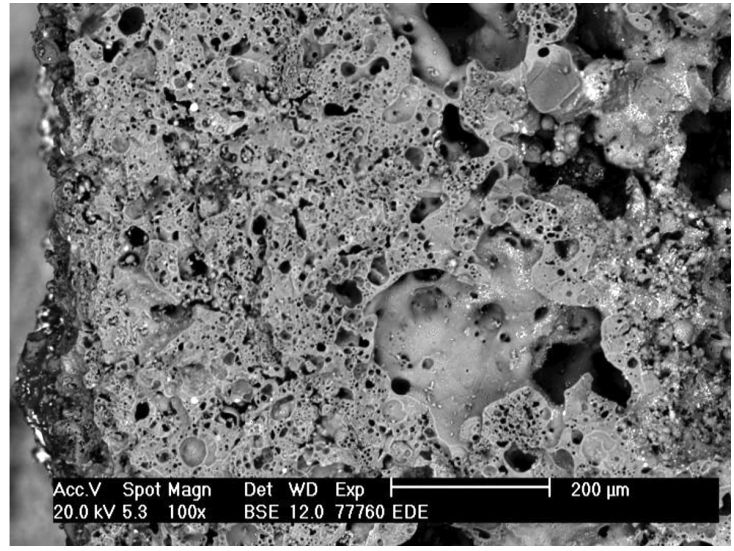

Figure 5: Closed structure of the FA2 sample

Slika 5: Zaprta struktura vzorca FA2

homogeneous structure of FA2 and Figure 6 shows the swollen core of the sample based on FA3s causing an enclosed surface.

\section{CONCLUSIONS}

When assessing the suitability of fly ash, the main difference can be seen between the high-temperature fly ash and the FBC ash. The first type mainly contains high-temperature minerals like mullite. The FBC ashes mainly contain anhydrite and free lime, which increase the manipulation strength of fresh samples, but they also increase the amount of mixing water, weakening the sintered fly-ash body and creating open porosity. The FBC ashes are not very suitable for sintered aggregates.

When assessing the influence of the quality of high-temperature fly ash on the quality of an ash body, the main parameters are the loss on ignition, the remains on the sieve of $0.009 \mathrm{~mm}$, the contents of $\mathrm{SiO}_{2}, \mathrm{Fe}_{2} \mathrm{O}_{3}$, quartz, mullite and the amorphous phase. The maximum loss on ignition is $8 \%$. Higher values classify the ash as a fuel. Finer ashes create more solid structures with small pores at lower temperatures. A higher content of $\mathrm{SiO}_{2}$ in the amorphous phase ensures a higher strength.

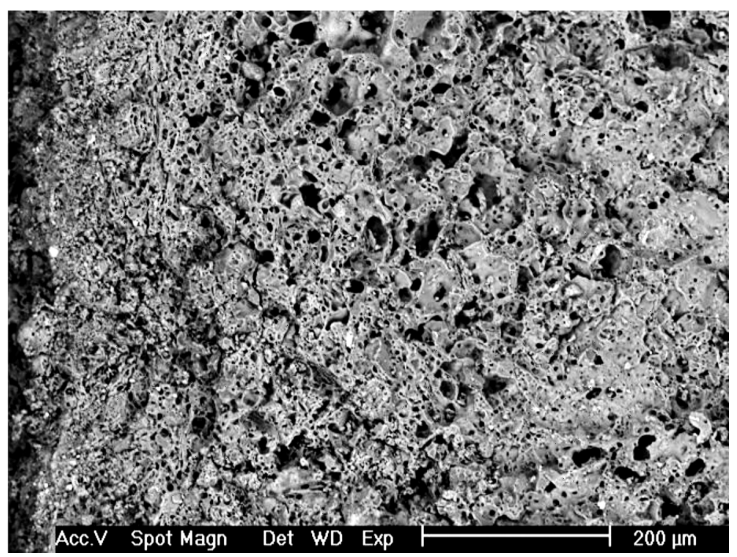

Figure 6: Swollen surface of the FA3s sample Slika 6: Napihnjena površina vzorca FA3s 
A higher content of mullite needs a higher temperature for creating a solid structure. The content of $\mathrm{Fe}_{2} \mathrm{O}_{3}$ together with carbon finally works as a very effective fluxing agent. Thus, the surface of a specimen is sintered faster and the firing product gases of $\mathrm{CO}$ and $\mathrm{CO}_{2}$ can cause a considerable swelling.

Further work will focus on the influence of a faster temperature rise during the annealing microscopy on the area change and the impact of increasing the firing temperature to $1200^{\circ} \mathrm{C}$ on the physico-mechanical parameters and mineralogical changes.

\section{Acknowledgements}

The Czech Science Foundation Project P104-1330753P "Study of the process of creating fly ash body" and the European Union's "Operational Programme Research and Development for Innovations", No. CZ.1.05/2.1.00/03.0097, as an activity of the regional Centre AdMaS, "Advanced Materials, Structures and Technologies", are gratefully acknowledged.

\section{REFERENCES}

${ }^{1}$ Act on Waste No. 185/2001 Coll., as amended, Decrees of the Ministry of the Environment No. 376/2001 Coll. and 381/2001 Coll., 2001
${ }^{2}$ R. Zárubová, Utilisation of coal combustion products from power and heat stations for remediation of open pit mines in the Czech Republic, Proc. of the 1st Symposium on flue gas desulphurization, 4th Symposium on ash, slag and waste landfils in power plants and mines, Palič, 2012, 246-250

${ }^{3}$ P. Kulhankova, Secondary raw materials policy of the Czech Republic 2012-2030, Proc. of the Inter. Conf. Recycling 2012, Brno, 2012, 72-76

${ }^{4}$ H. Al-Khaiat, N. Haque, Strength and durability of lightweight and normal weight concrete, Journal of Materials in Civil Engineering, 11 (1999), 231-235, doi:10.1061/(ASCE)0899-1561(1999)11:3(231)

${ }^{5}$ O. Kayali, M. N. Haque, B. Zhu, Some characteristics of high strength fiber reinforced lightweight aggregate concrete, Cement and Concrete Composites, 25 (2003), 207-213, doi:10.1016/S09589465(02)00016-1

${ }^{6}$ B. Yun, I. Ratiyah, P. A. M. Basheer, Properties of lightweight concrete manufactured with fly ash, furnace bottom ash, and Lytag, International Wokshop on Sustainable Development and Concrete Technology, Beijing, 2004, 77-88

${ }^{7}$ S. Slabaugh, Ch. Swan, R. Malloy, Development and properties of Foamed synthetic Lightweight Aggregates, World of Coal Ash Conference, Kentucky, 2007

${ }^{8}$ H. Ecke, H. Sakanakura, T. Matsuto, N. Tanaka, A. Lagerkvist, State-of-the-art treatment processes for municipal solid waste incineration residues in Japan, Waste Manag. Res., 18 (2000), 41-51, doi:10.1034/j.1399-3070.2000.00097.x

${ }^{9}$ A. Mueller, S. N. Sokolova, V. I. Vereshagin, Characteristics of lightweight aggregates from primary and recycled raw materials, Construction and Building Materials, 22 (2008), 703-712, doi:10.1016/j.conbuildmat.2007.06.009

${ }^{10}$ R. Sokolar, Ceramics, Publishing house VUTIUM, Brno 2006 (in Czech) 